\title{
Absence of both circadian rhythm and Trypanosoma cruzi periodicity with xenodiagnosis in chronic chagasic individuals
}

\author{
Ausência de nitmo circadiano e de periodicidade do Trypanosoma cruzi \\ ao xenodiagnóstico em chagásicos crônicos
}

\author{
Cleudson Castro ${ }^{1}$ and Aluizio Prata ${ }^{2}$
}

\begin{abstract}
Xenodiagnoses were performed every 3 hours using 10 Triatoma infestans $3^{\text {rd }}$ instar for 24 to 72 hours, in 18 chronic chagasics with positive serology and/or xenodiagnosis. There was no statistically significant difference in the positivity of assays performed during the day (9:00 to 18:00h) compared to those performed at night (21:00 to 6:00h), $\left(\chi^{2}=0.1526 p=0.696\right)$. Xenodiagnosis was performed in ten of the patients for 13 successive days but there was no periodicity detected in the positive assays.
\end{abstract}

Key-words: Circadian rhythm. Trypanosoma cruzi parasitemia. Serial xenodiagnoses.

Resumo Realizamos xenodiagnósticos de 3 em 3 horas com 10 ninfas do $3^{\circ}$ estágio de Triatoma infestans por um período de 24 a 72 horas, em 18 chagásicos crônicos que tinham sorologia e/ou xenodiagnóstico positivos. Não houve diferença estatisticamente significante na positividade entre os testes realizados durante o dia (9:00 às 18:00h) e à noite (21:00 às 6:00h), $\left(\chi^{2}=0,1526 p=0,696\right.$ ). Dez dos pacientes fizeram também xenodiagnósticos diários, durante 13 dias sucessivos, não havendo periodicidade dos testes positivos.

Palavras-chaves: Ritmo circadiano. Parasitemia pelo Trypanosoma cruzi. Xenodiagnósticos seriados.

Some authors have expressed interest regarding the study of the circadian rhythm of trypanosomes in primates ${ }^{3}$ and other animals ${ }^{4813}$. Nevertheless, despite the extensive literature at hand on Trypanosoma cruzi biology, untill 1975, no report existed about the circadian rhythm of this parasite ${ }^{6}$. In 1977, the first publication reporting the nychthemeral behavior of $T$. cruzi in the peripheral blood of a chronically infected patient appeared ${ }^{9}$. Only recently experimental works on this matter have been presented ${ }^{5101112}$. With a view to contributing to a better knowledge of the theme, we present the result of xenodiagnoses carried out several times a day and on successive days, as previously mentioned $^{12}$.

\section{MATERIAL AND METHODS}

The work was performed in chronically $T$. cruzi infected adult male and female individuals, hospitalized in the Sanatório Espírita of Anápolis, Goiânia State, Brazil, or pertaining to the Military Police of Sobradinho city, DF. All patients were both serology and/or xenodiagnosis (xeno) positive for chagasic infection and they were hospitalized for the study of parasitemia. A xenodiagnosis was scheduled for each patient, every three hours with 10 Triatoma infestans $3^{\text {rd }}$ instar, totaling eight tests every 24 hours. In some patients, besides the above-mentioned assays, xenodiagnoses were scheduled once a day during 13 successive days. The results of the tests

1. Núcleo de Medicina Tropical e Nutrição da Universidade de Brasília (UnB), DF, 2. Disciplina de Doenças Infecciosas e Parasitárias da Faculdade de Medicina do Triângulo Mineiro, Uberaba MG, Brasil.

Address to: Prof. Cleudson Castro. Núcleo de Medicina Tropical e Nutrição/UnB, Caixa Postal 04671, 70919-970 Brasília, DF, Brazil Fax: 55612732811

Recebido para publicação em 21/7/98. 
were expressed as either positive or negative after microscopic assay of a pool of feces between lamina and laminula, resulting from abdominal compression to a minimum of seven and to the maximum of 10 triatomines. The tests were performed prior to specific treatment with benznidazol.

\section{RESULTS}

For the study of parasitemia 18 patients were tested, 13 men and 5 women. Ten performed tests during 24 hours, 4 during 48 hours and 4 during 72 hours, 2 during 45 hours and 1 during 21 hours consecutively (Table 1). A total of 237 xenodiagnoses were performed. Out of these, $87(36.7 \%)$ were positive (Table 2). For 3 patients all xenodiagnoses were negative. The patient that presented greater positivity had $22(91.7 \%)$ positive xenodiagnoses in 24 tests. At a significance of $1 \%$, no statistical difference was observed in the positivity of the tests in the different schedules. If we consider the daily positivity from 9 a.m. to 6 p.m., and the nocturnal period from 21 p.m. up to 6 a.m., no significant statistical difference was verified between these two periods $(p=0.696)$.

Table 1 - Results of xenodiagnoses performed in 18 patients with the number of tests and the percentage of positivity

\begin{tabular}{lccc}
\hline & & Xenodiagnoses & \\
\cline { 2 - 4 } Patients & performed & positive & 37.5 \\
\hline ASS & 8 & 3 & 87.5 \\
HPC & 8 & 7 & 25.0 \\
LS & 8 & 2 & 12.5 \\
AMFL & 8 & 1 & 25.0 \\
ARS & 8 & 2 & 50.0 \\
LMS & 8 & 4 & 75.0 \\
AMA & 8 & 6 & 50.0 \\
MMC & 8 & 4 & 62.5 \\
BPS & 8 & 5 & 85.7 \\
FJO & 7 & 6 & 20.8 \\
NA & 24 & 5 & 16.7 \\
JMD & 24 & 4 & - \\
JFS & 24 & 0 & 91.7 \\
IAM & 24 & 22 & - \\
JCP & 15 & 0 & 46.7 \\
FCA & 15 & 7 & -
\end{tabular}

Table 2 - Xenodiagnoses performed in 18 individuals, every 3 hours.

\begin{tabular}{lccc}
\hline & & Xenodiagnoses & \\
\cline { 2 - 4 } Hours & performed & positive & \% \\
\hline 3 & 29 & 12 & 41.4 \\
6 & 30 & 12 & 40.0 \\
9 & 28 & 8 & 28.6 \\
12 & 28 & 9 & 32.1 \\
15 & 31 & 13 & 41.9 \\
18 & 30 & 11 & 36.7 \\
21 & 30 & 8 & 26.7 \\
24 & 31 & 14 & 45.2 \\
\hline Total & 237 & 87 & 36.7 \\
\hline
\end{tabular}

diurnal schedule from 9 a.m. to 6 p.m. versus nocturnal from 9 p.m. to 6 a.m. $\chi^{2}=0.1526, p=0.696$. 
In the evaluation of the parasitemia over 13 successive days, 10 of the patients were studied as follows: 7 during each day, 2 during 12 days, and one performed 9 xenodiagnoses in the period of 13 days (Table 3 ). Out of the 124 xenodiagnoses in successive days, $47(37.9 \%)$ were positive.
For 2 of the individuals with 13 successive xenodiagnoses all the tests were negative. One presented 12 positive results and another, 10 (Table 3). Observing the sequence of the tests performed (Table 3), no evidence of periodicity was detected.

Table 3 - Results of xenodiagnoses of 10 patients who performed tests several times a day and once a day, in 13 successive days.

\begin{tabular}{|c|c|c|c|c|c|c|c|c|c|c|}
\hline \multirow[t]{2}{*}{ Time } & \multicolumn{10}{|c|}{ Patients } \\
\hline & ASS & HPC & LS & AMFL & ARS & LMS & AMA & MMC & BPS & FJO \\
\hline hour & \multicolumn{10}{|c|}{ xenodiagnosis every 3 hours } \\
\hline 3 & + & + & - & - & + & + & + & + & + & - \\
\hline 6 & + & + & - & - & - & + & - & + & + & + \\
\hline 9 & + & + & - & - & - & - & - & - & + & \\
\hline 12 & - & + & - & + & - & - & + & - & - & + \\
\hline 15 & - & + & + & - & - & - & + & - & - & + \\
\hline 18 & - & + & + & - & - & + & + & + & + & + \\
\hline 21 & - & + & - & - & - & - & + & - & - & + \\
\hline 24 & - & - & - & - & + & + & + & + & + & + \\
\hline day & \multicolumn{10}{|c|}{ daily xenodiagnosis } \\
\hline $1^{\circ}$ & - & - & - & + & + & - & - & + & - & + \\
\hline $2^{\circ}$ & - & - & - & - & - & - & - & + & - & + \\
\hline $3^{\circ}$ & - & - & - & + & + & - & + & - & & + \\
\hline $4^{\circ}$ & - & - & - & - & + & - & + & + & + & - \\
\hline $5^{\circ}$ & - & + & - & - & - & - & + & + & & + \\
\hline $6^{\circ}$ & - & - & - & - & + & - & - & + & - & + \\
\hline $7^{\circ}$ & - & - & - & - & + & - & - & + & & - \\
\hline $8^{\circ}$ & + & - & - & - & - & - & - & + & - & + \\
\hline $9^{\circ}$ & - & + & - & - & + & - & - & + & - & + \\
\hline $10^{\circ}$ & - & + & - & - & + & - & + & + & & + \\
\hline $11^{\circ}$ & + & + & - & - & - & - & + & + & - & + \\
\hline $12^{\circ}$ & - & + & - & + & + & - & + & + & - & + \\
\hline $13^{\circ}$ & - & & - & - & & - & - & + & - & - \\
\hline
\end{tabular}

\section{DISCUSSION}

The most common and important biological rhythm is that of 24 hours known as circadian rhythm which includes both the diurnal and nocturnal periods. Its purpose is to benefit the parasite, thus facilitating the spreading of the species. Sporadically, researchers have aroused interest regarding the study of the trypanosomes' circadian rhythm. A study of this kind has already been performed with the Trypanosoma minasense in Brazilian primates with the observation that this parasite is more numerous in peripheral blood at midday and at sunset than in the morning and midnight ${ }^{3}$. Also the circadian rhythm of
Trypanosoma congolense was studied in the peripheral blood of mice, and the greatest number of parasites was observed at 10 p.m. T. congolense showed a well-established cycle in mice whereas $T$. vivax, T. brucei and T. lewisi presented lessdefined cycles 7 . The fact that the circadian rhythm of $T$. congolense varies according to the host must be emphasized. Among cattle, this parasite reaches a higher parasitemia when blood is collected from the ear, at 7 a.m., with an environmental temperature of $17^{\circ} \mathrm{C}$, then at noon at $36^{\circ} \mathrm{C}$. The detection of a greater number of $T$. rotatorium in the blood of frogs starts at 4a.m., reaching a 
maximum at 4 p.m. The periodicity of this tripanosoma seems to be related to the intensity of light to which the frog is submitted. At night the parasites are scarce ${ }^{13}$. In this same host, the T. parvum is more numerous in the blood at night then during the day ${ }^{6}$. The African trypanosomes do not show a defined rhythm and up to 1975 no study on T. cruzi circadian rhythm existed ${ }^{6}$.

Studies into the T. cruzi circadian rhythm in man and animals are equally scarce. The only study on humans as far as we know was performed by Schenone et al in 1977, in a chronic chagasic patient with high parasitemia. For this patient xenodiagnosis was performed at midday and midnight during 15 consecutive days, and it was observed that there was an equal infection in both periods ${ }^{9}$. Using experimental animals, it was seen that in mice, during the acute phase, and in both guinea-pigs and mice, in the chronic phase, there is no circadian rhythm for T. cruzil ${ }^{11}$. The study performed by hemoscope and xenodiagnosis showed that the positive tests were frequent but not cyclic during the 24-hour period.

The tests resulted positive in all the scheduled periods for each patient, thus showing that xenodiagnosis can be performed effectively at any time, both during the day or at night.

\section{REFERENCES}

1. Castro C, Prata A. Estudo da parasitemia do T. cruzi no chagásico crônico, várias vezes ao dia. Revista da Sociedade Brasileira de Medicina Tropical 24(supl I):8, 1991.

2. Castro C, Prata A. Estudo da parasitemia diária pelo T. cruzi no chagásico crônico. Revista da Sociedade Brasileira de Medicina Tropical 25 (supl):33, 1992.

3. Deane LM, Silva JE, Loures Filho L. Circadian rhythm in the parasitaemia of the primate haemoflagellates, Trypanosoma minasense. Transaction of the Royal Society of Tropical Medicine and Hygiene 67:424-425, 1973.

4. Deane LM, Silva JE, Loures Filho L. Nycthemeral variation in parasitaemia of Trypanosoma minasense in naturally infected marmosets of the genus Callithrix (Primates, Callithricidae). Revista do Instituto de Medicina Tropical de São Paulo 16:1-6, 1974.

5. Goldsmith RS, Zárate LG, Zárate R, Lobo E. Enhancement of parasitemia by serial xenodiagnosis on primates chronically infected with Chagas' disease. In: Anais do Congresso Internacional sobre Doença de Chagas, Rio de Janeiro, p. 11, 1979.

6. Hawking F. Circadian and other rhythms of parasites. In: Dawes B (ed) Advances in Parasitology, Academic Press, London, 13:123-182, 1975.

7. Hawking F. Circadian Rhythms of Trypanosoma congolense in laboratory rodents. Transaction of the Royal Society of Tropical Medicine and Hygiene 72:592$595,1978$.
8. Hornby HE, Bailey HW. Diurnal variation in the concentration of Trypanosoma congolense in the blood-vessels of the ox's ear. Transaction of the Royal Society of Tropical Medicine and Hygiene 24:557-564, 1930/1931.

9. Schenone H, Rojo M, Rojas A, Concha L. Positividad diurna y nocturna del xenodiagnostico en un paciente con infeccion chagasica cronica de parasitemia permanente. Boletin Chileno de Parasitologia 32:63-66, 1977.

10. Sherlock IA. Novas observações sobre a inexistência de ritmo circadiano para o T. cruzi. In: Resumos do XVI Congresso da Sociedade Brasileira de Medicina Tropical, Natal, trabalho $\mathrm{n}^{\circ}$ 108, 1980,

11. Sherlock IA. Parasitemia constante durante 24 horas consecutivas na infecção experimental pelo T. cruzi. Revista da Sociedade Brasileira de Medicina Tropical 17:137-144, 1984.

12. Sherlock IA, Guitton N, Muniz TM. Positividade durante 24 horas consecutivas do xenodiagnóstico em camundongos na fase aguda da infecção pelo $T$. cruzi. In: Resumos do XIV Congresso da Sociedade Brasileira de Medicina Tropical e III Congresso da Sociedade Brasileira de parasitologia, João Pessoa, p. 73, 1978.

13. Southworth GC, Mason G, Seed JR. Studies on frog Trypanosomiasis. I. A 24-hour cycle in the parasitaemia level of Trypanosoma rotatorium in Rana clamitans from Louisiana. The Journal of Parasitology 54:255-258, 1968. 